\title{
Effect of Acid Whey Addition for Sewage Sludge Co-Digestion on the Nitrogen and Phosphorus Release
}

\author{
Marta Bis ${ }^{1}$ \\ 1 Faculty of Environmental Engineering, Lublin University of Technology, Nadbystrzycka 40 B, 20-618 Lublin, \\ Poland \\ e-mail:m.bis@pollub.pl
}

\begin{abstract}
This study examined the influence of acid cheese whey (ACW) addition on the nitrogen and phosphorus release in the co-digestion with sewage sludge (SS). The laboratory installation consisted of two semi-flow anaerobic digesters operating under mesophilic conditions. The concentrations of total nitrogen (TN), total phosphorus (TP), $\mathrm{NH}_{4}^{+}-\mathrm{N}$ and $\mathrm{PO}_{4}^{3-}-\mathrm{P}$ in the feedstock and the digestate were determined together with the appropriate release factors. The results indicate that the co-digestion of SS with ACW did not cause a significant increase in the concentration of biogenic elements both in the reactor feedstock and the digestate. Lower concentration of total nitrogen and total phosphorus was achieved in the digestate, both in whey and reference runs, probably due to partial retention in the digesters due to the precipitation processes.
\end{abstract}

Keywords: anaerobic fermentation process, co-digestion, cheese whey, digestate quality, nitrogen and phosphorus release

\section{INTRODUCTION}

Anaerobic digestion (AD) is considered the most effective method of waste activated sludge management due to the environmental and economic benefits. It provides both safe and costeffective sludge stabilization and ensures clean energy production [Kim et al., 2013, Feki et al., 2020]. The biogas generation in the AD processes represents one of the most environmentally friendly methods of energy production [Stefaniuk and Oleszczuk, 2015], while the enhancement of biogas yield has been the object of numerous studies [Kim et al., 2013; Zhen et al., 2017; Elalami et al., 2019]. An effective way to improve the biogas production efficiency is the co-digestion of multiple substrates with complementary characteristics. Co-digestion allows for better adjustments of $\mathrm{pH}$, moisture, and the nutrients balance, which affects the microbial consortia diversity and its synergistic effects [Xu et al., 2018]. Additional benefits of co-digestion include dilution of potential toxic compounds, increased load of biodegradable organic matter and supplement of trace elements [Sosnowski et al., 2003; Xu et al., 2018]. Due to the high organic content and high biogas potential, cheese whey $(\mathrm{CW})$ can be used as a substrate in the anaerobic digestion process.

Cheese whey is a liquid by-product of the processes for the production of cheese and acid casein, represents up to $95 \%$ of the milk volume and retains about $55 \%$ of the milk nutrients [Charalabmous et al., 2020]. About $93 \%$ of $\mathrm{CW}$ is water, while among the total solids ingredients are carbohydrates (lactose) (70-72\%), whey proteins $(8-10 \%)$ and minerals, mainly calcium, potassium, sodium and magnesium salts (12-15\%). Whey also contains milk fat (triglycerides, diglycerides, fatty acids, phospholipids), trace amounts of non-protein nitrogen compounds and B group vitamins [De Witt, 2001, Ryan and Walsh, 2016]. Due to the high lactose content, the $\mathrm{CW}$ has high COD $(50-80 \mathrm{~g} / \mathrm{L})$ and $\mathrm{BOD}_{5}$ values $(40-60 \mathrm{~g} / \mathrm{L})$ [Chatzipaschali and Stamatis, 2012]. Depending on the production process and technological parameters, $\mathrm{CW}$ is divided into acid whey $(\mathrm{pH}$ $<5)$ and sweet whey $(6<\mathrm{pH}<7)$. Acid cheese whey $(\mathrm{ACW})$ is a by-product of a cottage cheese 
production, has a lower $\mathrm{pH}$ and protein content as well as higher concentration of mineral salts and lactic acids.

The large volumes of ACW constitute a major problem; for the production of $1 \mathrm{~kg}$ of cheese, about $9 \mathrm{~kg}$ of whey can be generated from every $10 \mathrm{~kg}$ of milk [Prazeres et al., 2012]. Additionally, cheese whey is considered the most contaminated liquid waste generated by the dairy industries, and its utilization is now a serious ecological and economic problem [Charalabmous et al., 2020]. Cheese whey management has been focused on the application of biological and physicochemical treatment, valorization technologies to recover valuable compounds such as proteins and lactose as well as direct land application. The use of liquid whey generates significant costs associated with its transport and storage, while drying and recovery of substances require considerable financial and energy costs, which are not normally acceptable to small and medium factories [Chatzipaschali and Stamatis, 2012]. Thus, the biological process by anaerobic digestion constitutes a viable and very attractive alternative of the acid whey management. However, whey is considered a difficult substrate of co-digestion, due to high salinity and low alkalinity, which may result to accumulation of volatile fatty acids (VFA) and methanogenic process inhibition [Treu et al., 2019]. In addition, whey has tends to acidify due to its very high biodegradability. Several studies have examined the effect of co-digestion of ACW with manure [Hublin and Zelic, 2013; Bertin et al., 2013], sewage sludge [Maragkaki et al., 2017; 2018], slurry and fish ensilage [Vivekanand et al., 2018] and potato stem [Martinez-Ruano et al., 2019]. These studies showed that ACW improved the $\mathrm{C} / \mathrm{N}$ ratio in the feedstock and increased the availability of readily biodegradable organic substances [Rico et al., 2015]. However, in most studies, the optimization of co-digestion process focuses on enhancing the biogas yields, neglecting the issues of digestate quality.

Apart from biogas, anaerobic digestion processes also generate digestate, the composition of which mainly depends on the substrate characteristics as well as the operating conditions and configuration of digestion system [Logan and Visvanathan, 2019; Czekała et al., 2020]. The digestate contains macronutrients (N, $\mathrm{P}, \mathrm{K}, \mathrm{Ca}, \mathrm{S}$ and $\mathrm{Mg}$ ), micronutrients $(\mathrm{B}, \mathrm{Cl}, \mathrm{Mn}, \mathrm{Fe}, \mathrm{Zn}, \mathrm{Cu}, \mathrm{Mo}$ and $\mathrm{Ni}$ ), and bioactive substances such as phytohormones, nucleic acids and vitamins [Logan and
Visvanathan, 2019]. The nutrients in the digestate have a more organic form, which leads to greater biological stability, and its content largely determines the subsequent use of digestate [Möller and Müller, 2012].

The digestate processing can be approached in three ways: first: digestate recycling in municipal wastewater treatment plants (WWTPs), second: utilization as crop fertilizer or soil improver, and third: digestate processing technologies (e.g. recovering nutrients, struvite precipitation, microalgal cultivation, biofuel and bioethanol production) [Fuchs and Drogs, 2013; Escalante et al., 2018; Peng and Pivato, 2019; Peng et al., 2020a]. In Poland, digestate is classified as waste [Act of 14 December 2012 On Waste], which causes problems in its use. For better digestate management, the distribution of nutrients between liquid ( $80-90 \%$ by mass) and solid fraction ( $10-20 \%$ by mass) can be used [Tampio, 2016; Xia and Murphy, 2016]. The organic-rich solid fraction can be applied as an agricultural fertilizer or could be converted to heat or products like pyrochar or nanocellulose via thermal processes [Xia and Murphy, 2016]. However, due to significant content of macroelements ( $\mathrm{N}, \mathrm{P}$ and $\mathrm{K})$ liquid digestate is most often applied as fertilizer on local agricultural land [Elalami et al, 2019; Voca et al., 2005]. Unfortunately, direct application to crops may cause the contamination with heavy metals, pathogen transmission, and by ammonium emission it could contribute to the eutrophication of the nearby water systems [Xia and Murphy, 2016]. In order to address these problems, other solutions must be used for digestate processing, particularly those which apart from solving the problem, also provide additional financial benefits. The digestate processing methods include among others biochar production through pyrolysis [Monlau et al., 2016], precipitation of phosphorus in the form of struvite, or ammonium nitrogen recovery for the fertilizers production [Vaneeckhaute et al., 2017]. Digestate can be an ingredient in substrate recipes in mushroom cultivation [O'Brien et al., 2019] or electron donors of denitrification for the treatment of mature landfill leachate [Peng et al., 2018; 2020b]. The future prospects include microalgal cultivation or bioethanol production [Logan and Visvanathan, 2019].

Due to the intensive development of the biogas industry, extensive research on determining the cost-effective digestate processing technologies is required. Additionally, the optimization 
of the AD process, in addition to increasing the biogas efficiency, should include an equally important aspect of the quality of digestate produced [Logan and Visvanathan, 2019 Tambone et al., 2010]. The composition of digestate is highly variable and influenced by kind of feedstock and digestion process characteristics; therefore, it should be determined with every modification of system and process parameters [Akhiar et al., 2017; Teglia et al., 2011; Zirkler et al., 2014]. However, investigations on the physico-chemical characteristics of the digestate are not always carried out, especially in the field of co-digestion of sewage sludge and cheese whey. Therefore, this paper focuses on the impact of the addition of acid whey on digestate quality, particularly in the scope of the nitrogen and phosphorus release.

\section{MATERIALS AND METHODS}

\section{Material characteristics - sewage sludge (SS) and acid cheese whey (ACW)}

Sewage sludge, which was a main substrate, was sourced from Puławy municipal wastewater treatment plant (WWTP), while co-substrate (ACW) was provided by the District Dairy Cooperative in Piaski (Poland). The sludge was mixed at the volume ratio 60:40 (primary: waste sludge), then homogenized, manually screened through a 3 -mm screen and partitioned. The sludge samples were stored in a laboratory refrigerator at $4^{\circ} \mathrm{C}$ for a week at the longest. The ACW sampling took place each time before starting the next series of experiment; the samples were homogenized, portioned and stored in a laboratory freezer in $-25^{\circ} \mathrm{C}$.
Prior to the feedstock preparation, the whey was warmed to the room temperature. The characteristics of SS and ACW are presented in Table 1.

The inoculum used in the experiments was obtained from a mesophilic anaerobic digester operating at HRT of $25 \mathrm{~d}$ from the Pulawy WWTP. The inoculum was incubated for 30 days for biomass adaptation.

\section{Laboratory installation}

The co-digestion of SS and ACW was conducted in semi-flow anaerobic reactors. The laboratory installation consisted of two reactors made from stainless steel with a volume of $40 \mathrm{~L}$. Their shape corresponded to a typical construction designed on a technical scale and included a cylindrical part and two parts in the form of truncated cones equipped with heating jacket filled with distilled water. The reactors were heated to maintain a constant temperature of $35^{\circ} \mathrm{C} \pm 0.1^{\circ} \mathrm{C}$, which corresponded to the mesophilic conditions and operated under full mixing conditions using a mechanical stirrer with a rotational speed of $50 \mathrm{~min}^{-1}$. The reactors were fed in a quasi-flow system, once a day, by means peristaltic pumps. Moreover, the laboratory installation was equipped with the tanks for feeding and receiving waste digestate and a biogas installation including pipelines, a pressure equalizing tank, a mass flow matter with automatic data recording, shut-off valves, a gas sampler and a dewatering connector.

\section{Experimental design}

The study comprised two experiments: Experiment 1 aimed to evaluate the digestate quality in two-component systems of SS and ACW.

Table 1. Composition of the ACW and SS used in the experiments

\begin{tabular}{|c|c|c|c|c|c|}
\hline \multirow{2}{*}{ Parameter } & \multirow{2}{*}{ Unit } & \multicolumn{2}{|c|}{ ACW (average value and standard deviation) } & \multicolumn{2}{|c|}{ SS } \\
\cline { 3 - 5 } & & $\mathrm{R} 1.2$ & $\mathrm{R} \mathrm{2.2}$ & Average & $95 \%$ confidence limits \\
\hline $\mathrm{COD}$ & $\mathrm{mg} \mathrm{L}^{-1}$ & $75189 \pm 409$ & $69328 \pm 201$ & 53240 & $51400 / 55090$ \\
\hline $\mathrm{SCOD}$ & $\mathrm{mg} \mathrm{L}^{-1}$ & $67257 \pm 242$ & $62182 \pm 225$ & 3147 & $2927 / 3368$ \\
\hline $\mathrm{VFA}$ & $\mathrm{mg} \mathrm{L}^{-1}$ & $5978 \pm 22.6$ & $5093 \pm 14.1$ & 1747 & $1585 / 1909$ \\
\hline $\mathrm{pH}$ & & $4.58 \pm 0.21$ & $3.51 \pm 0.83$ & 5.83 & $5.78 / 5.88$ \\
\hline Alkalinity & $\mathrm{mg} \mathrm{L}^{-1}$ & - & - & 875 & $788 / 961$ \\
\hline $\mathrm{TS}$ & $\mathrm{g} \mathrm{kg}^{-1}$ & $44.2 \pm 2.3$ & $42.7 \pm 2.4$ & 34.8 & $33.9 / 35.7$ \\
\hline $\mathrm{VS}$ & $\mathrm{g} \mathrm{kg}^{-1}$ & $37 \pm 2.4$ & $35.7 \pm 2.6$ & 26.1 & $25.3 / 26.9$ \\
\hline $\mathrm{TN}$ & $\mathrm{mg} \mathrm{L}^{-1}$ & $7899 \pm 192$ & $1011 \pm 36$ & 2920 & $2866 / 2974$ \\
\hline $\mathrm{TP}$ & $\mathrm{mg} \mathrm{L}^{-1}$ & $868 \pm 35.1$ & $732 \pm 12.3$ & 1038 & $709 / 1367$ \\
\hline $\mathrm{NH}_{4}{ }^{+}-\mathrm{N}$ & $\mathrm{mg} \mathrm{L}^{-1}$ & $75.8 \pm 2.8$ & $60.9 \pm 3.2$ & 96.7 & $52.7 / 140.7$ \\
\hline $\mathrm{PO}_{4}{ }^{3-}-\mathrm{P}$ & $\mathrm{mg} \mathrm{L}^{-1}$ & $688 \pm 42.7$ & $539 \pm 32.4$ & 123.1 & $88.2 / 158.1$ \\
\hline
\end{tabular}


Experiment 2 was conducted to evaluate the system sensitivity of the slightly enhanced HRT. Both of experiments included two runs, carried out simultaneously in two parallel systems that lasted 90 days (30 days for acclimatization and 60 days for measurements). In the first run, each reactor was feed only SS for one hydraulic retention time (HRT). The detailed experimental settings are listed in Table 2.

\section{Analytical methods}

The SS and the feedstock composition (SS and ACW mixtures) were analyzed once a week, immediately after SS delivery to the laboratory. The composition of the ACW was determined before the start of each series of tests. In the SS and ACW samples, the analyzed parameters included COD, TS, VS, TN and TP. In the supernatant resulting from centrifugation of sludge, the soluble chemical oxygen demand (SCOD), VFA, alkalinity, $\mathrm{pH}$ level, ammonia nitrogen $\left(\mathrm{NH}_{4}^{+}-\mathrm{N}\right)$ and orthophosphate phosphorus $\left(\mathrm{PO}_{4}^{3-}-\mathrm{P}\right)$ were determined. The digestate composition was analyzed twice a week according to the same scheme as for the feedstock. All analyses were conducted in triplicate.

Most experimental analyses were carried out according to the Standard Methods for the Examination of Water and Wastewater [APHA, 2005]. All spectrophotometric measurements were determined with a Hach Lange UV-VIS DR 5000 spectrophotometer [Hach, Loveland, CO, USA]. The removal efficiency of TN and TP as well as release degree $\mathrm{f}_{\mathrm{NH} 4}$ and $\mathrm{f}_{\mathrm{PO} 4}$ were determined according to Montusiewicz [2012].

\section{RESULTS AND DISCUSSION}

The effect of whey addition on the sewage sludge co-digestion on the $\mathrm{TN}$ and $\mathrm{NH}_{4}^{+}-\mathrm{N}$ concentration in the feedstock and digestate is presented in Figure 1. The results show a slight increase in total nitrogen concentration in the feedstock when compared to the control samples (Fig. 1a). In the case of larger dose of whey (R1.2), a greater increase of TN (8.2\%) was observed compared do R2.2 (0.8\%). This was probably due to a higher nitrogen content of whey in experiment 1 (Table 1). It should be noticed that the SS characteristics varied throughout the experiments, as well as ACW composition differed between the experiment 1 and 2 . The changes of the TN concentration in whey are associated with the variable concentration of this component in the milk [Ong et al, 2013]. As a result of using ACW as a co-substrate, the TN concentration in the digestate remained at a level comparable to the controls. In SS, the average concentration was $3.7 \mathrm{~g} \mathrm{dm}^{-3}$ in run 1.1 and $2.8 \mathrm{~g} \mathrm{dm}^{-3}$ in run 2.1 , and in the presence of whey $-3.6 \mathrm{~g} \mathrm{dm}^{-3}$ in run 1.2 and $2.9 \mathrm{~g} \mathrm{dm}^{-3}$ in run 2.2. The available literature showed that only very little of organic nitrogen is assimilated by AD microorganisms [Sheets et al., 2015]. As a result, digestate usually contains high level of TN, which is mostly TAN, a combination of ammonium $\left(\mathrm{NH}_{4}^{+}\right)$and free ammonia $\left(\mathrm{NH}_{3}\right)$ [Fouda et al., 2013]. In this study from 74 to $92 \%$ of the nitrogen present in the feedstock remained in digestate.

Similarly as in the case of total nitrogen, the introduction of whey into the feed supplying the reactor resulted in a slight increase in the ammonia nitrogen content (1.7 in run 1.2 and $2.7 \%$ in run 2.2) as compared to the control samples (Fig. 1b). As a result of fermentation, a significant increase in the ammonium concentration was achieved in the digestate in all runs, which was the effect of ammonification [Montusiewicz, 2015]. Compared to SS, slightly lower ammonium nitrogen concentration in the digestate was recorded, by 14.5 and $13.8 \%$, respectively (run 1.2 and 2.2). In order to estimate the changes

Table 2. Experimental settings

\begin{tabular}{|c|c|c|c|c|c|c|c|}
\hline \multirow{3}{*}{ Run } & \multirow{3}{*}{$\begin{array}{c}\text { Feedstock } \\
\text { composition }\end{array}$} & \multicolumn{2}{|c|}{ Component volume } & \multirow{3}{*}{$\begin{array}{l}\text { SS:ACW volumetric ratio } \\
\text { BSG mass: } \\
\text { feedstock volume ratio* } \\
\mathrm{g} \mathrm{L}^{-1 *}\end{array}$} & \multirow{3}{*}{$\begin{array}{c}\text { HRT } \\
d \\
\end{array}$} & \multicolumn{2}{|c|}{ OLR } \\
\hline & & \multirow{2}{*}{$\begin{array}{c}\text { SS } \\
\mathrm{L}\end{array}$} & \multirow{2}{*}{$\frac{\mathrm{ACW}}{\mathrm{L}}$} & & & Avg. & $\begin{array}{l}\text { Upp./low. } \\
95 \% \text { mean }\end{array}$ \\
\hline & & & & & & \multicolumn{2}{|c|}{$\mathrm{kg} V S \mathrm{~m}^{-3} \mathrm{~d}^{-1}$} \\
\hline R 1.1 & SS (control) & 2.0 & - & 100 & 20 & 1.35 & $1.23 / 1.46$ \\
\hline R 1.2 & $\mathrm{SS}+\mathrm{ACW}$ & 1.8 & 0.2 & $90: 10: 00$ & 20 & 1.37 & $1.27 / 1.48$ \\
\hline R 2.1 & SS (control) & 2.0 & - & 100 & 20 & 1.49 & $1.41 / 1.58$ \\
\hline $\mathrm{R} 2.2$ & $\mathrm{SS}+\mathrm{ACW}$ & 2.0 & 0.2 & 91:09:00 & 18 & 1.61 & $1.53 / 1.68$ \\
\hline
\end{tabular}

HRT - hydraulic retention time, OLR - organic loading rate 


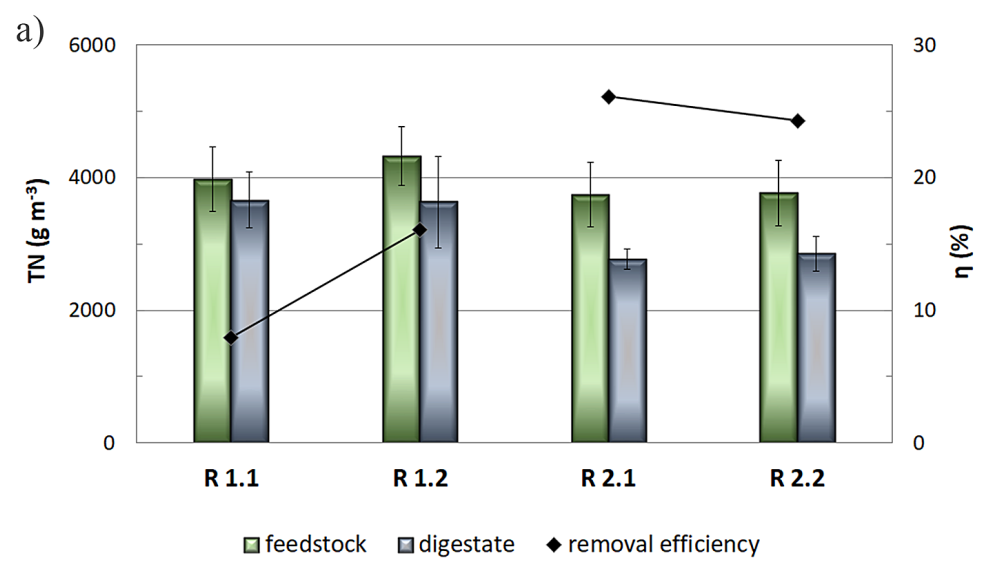

b)

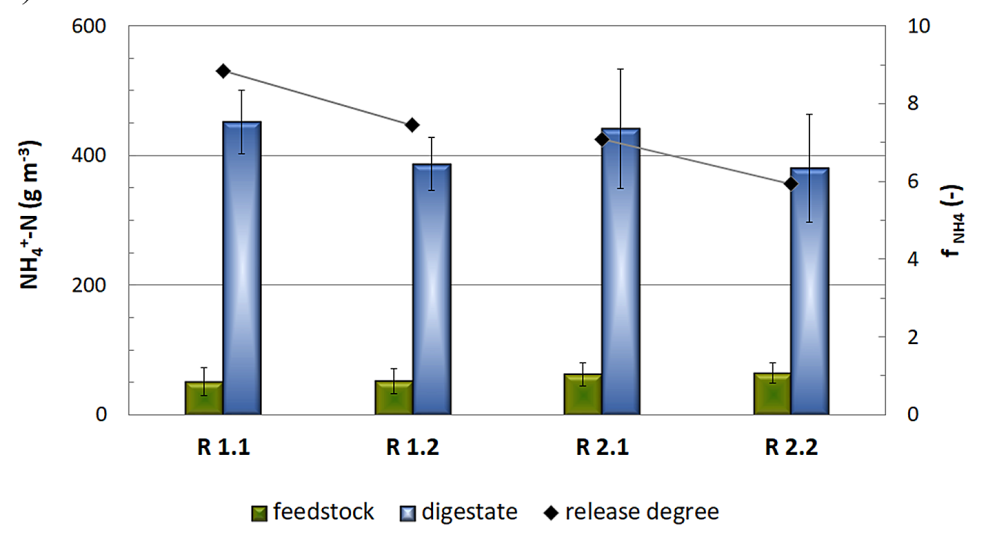

Fig. 1. Concentration of a) total nitrogen b) ammonium nitrogen in the feedstock and digestate (average values) and a) the removal efficiency of TN $\eta$ and $b$ ) release degree $\mathrm{f}_{\mathrm{NH} 4}$ (confidence interval limits $\alpha=0.05$ )

in the concentration of inorganic $\mathrm{N}$ forms, the release degree $\mathrm{f}_{\mathrm{NH} 4}$ was used, which was defined as a ratio of the reactor effluent load to influent load [Montusiewicz et al., 2013]. The value of release degree $\mathrm{f}_{\mathrm{NH} 4}$ for the co-digestion mixtures decreased from 8.8 (run 1.1) to 7.4 (run.1.2), and from 7.1 (run 2.1) to 5.9 (run. 2.2). High $\mathrm{NH}_{4}^{+}$content is of the great importance when using digestate for fertilization purposes, since nitrogen is an essential plant nutrient and $\mathrm{NH}_{4}^{+}$ is immediately available to the plant [Risberg et al., 2017]. In this study, the obtained $\mathrm{NH}_{4}^{+}-$ $\mathrm{N}$ : TN ratio in digestate was $0.11-0.16$ and was much lower than obtained in the fermentation of residue from agricultural crop production (0.5-0.69) [Fouda et al., 2013]. This observation was consistent with other studies suggesting that waste activated digestate had low $\mathrm{NH}_{4}{ }^{+}$-N due to the low nitrogen concentration in the activated sludge [Tampio et al., 2016].

The study also analyzed the changes of the total phosphorus concentration in the feedstock and digestate (Fig. 2a). A decrease of TP was found in the feedstock in the runs with $\mathrm{ACW}$, associated with the lower content of phosphorus in whey compared to SS. As a result of fermentation, a significant decrease in the TP concentration was observed in all runs, the efficiency of TP removal with $10 \%$ and $9 \%$ of whey was 48 and $57 \%$ respectively, while in reference $-31 \%$ and $58 \%$ in run 1.1 and 2.1 , respectively.

Comparing the results with the data in the literature, the removal efficiency obtained was usually lower, reaching up to 10-20\% [Möller and Müller, 2012; Montusiewicz et al., 2013; Montusiewicz, 2015]. Massé et al. [2007] obtained $25.5 \%$ retention of phosphorus during $\mathrm{AD}$ of swine manure, while in the anaerobically digested pig slurry $36 \%$ of $\mathrm{P}$ losses was indicated [Marcato et al. 2008]. The feasible explanation is the partial retention in the digesters due to the precipitation processes [Möller and Müller, 2012]. Marcato et al. [2008] observed crystals lining the digester composed of $\mathrm{P}, \mathrm{Ca}, \mathrm{Mg}$ and $\mathrm{Mn}$, while according the Suzuki et al. [2007] the main ingredient of the crystals lining the digester was struvite $\left(\mathrm{MgNH}_{4} \mathrm{PO}_{4} \cdot 6 \mathrm{H}_{2} \mathrm{O}\right)$. Banks et al. [2011] during the anaerobic digestion of food waste, also reported the losses of $\mathrm{N}$ and $\mathrm{P}$ related to the formation of struvite in the digester. 
In the presence of whey, an increase in orthophosphate concentration in the feedstock by $32 \%$ and $4,5 \%$ in run 1.2 and 2.2 was noted; however, the difference was not statistically significant (Fig. 2b). The values of $\mathrm{f}_{\mathrm{PO} 4}$ release degree were 0.9 in run 1.2 and 0.8 in run 2.2. respectively, which could indicate that orthophosphates were not released into digestate. In the case of sewage sludge digestion, an increase in the orthophosphate concentration was noted only in run 1.1, the value of $\mathrm{f}_{\mathrm{PO} 4}$ was 1.6 and 0.65 in run 1.1 and 2.1, respectively. However, if we consider the ratio of orthophosphate content in total phosphorus in digestate, which was $29 \%$ and $43 \%$ in run 2.1 and 2.2 , it is greater than the value of $25 \%$ and $31 \%$ in run 1.1 and 1.2 respectively. Similarly, these values were from 1.5 to 2.3 times higher than the corresponding coefficient for the feedstock. It is also known that the COD degradation is accompanied by the phosphate release [Przywara, 2006]. Therefore, it can be thought that phosphorus conversion and phosphate release were taking place.

The phosphorus content comes from adenylates, nucleic acids and phospholipids present in the feedstock [Möller and Müller, 2012], while chemical forms of orthophosphates and polyphosphates directly depends on the substrate composition, and above all on the $\mathrm{pH}$ and the presence of cations, in particular: $\mathrm{Ca}, \mathrm{Mg}, \mathrm{Al}, \mathrm{Zn}$ [Przywara, 2006]. In this study, the addition of whey contributed to lowering the $\mathrm{pH}$ and providing VFA, ACW addition contained more than $5000 \mathrm{mg} / \mathrm{L}$ of VFA (table 1). The $\mathrm{pH}$ in the feedstock was at a level $6.63 ; 6.33 ; 5.84$ and 5.62 in runs $1.1 ; 1.2 ; 2.1$ and 2.2 , respectively. The increase in the VFA concentration and the decrease in $\mathrm{pH}$ value below 7 created satisfying conditions for the phosphorusaccumulating organisms (PAOs), which release ortophosphates [Kleyböcker et al., 2012]. It can be supposed that such conditions contributed to the release of orthophosphate, but this phosphate release could not be observed as an increase in the phosphate concentration due to precipitation.

\section{CONCLUSIONS}

In this study, the co-digestion of $\mathrm{ACW}$ and sewage sludge on the nitrogen and phosphorus release was investigated. As a result of

a)

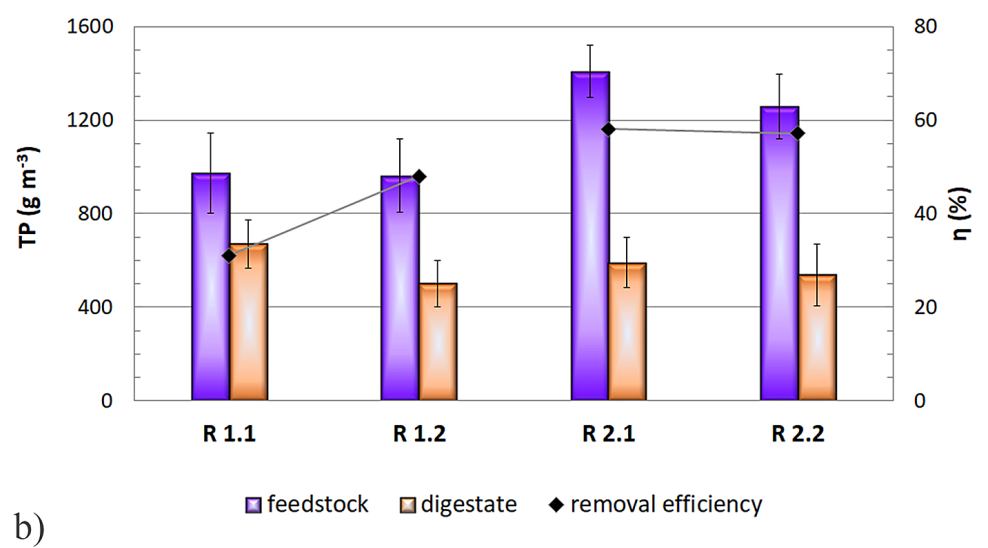

b)

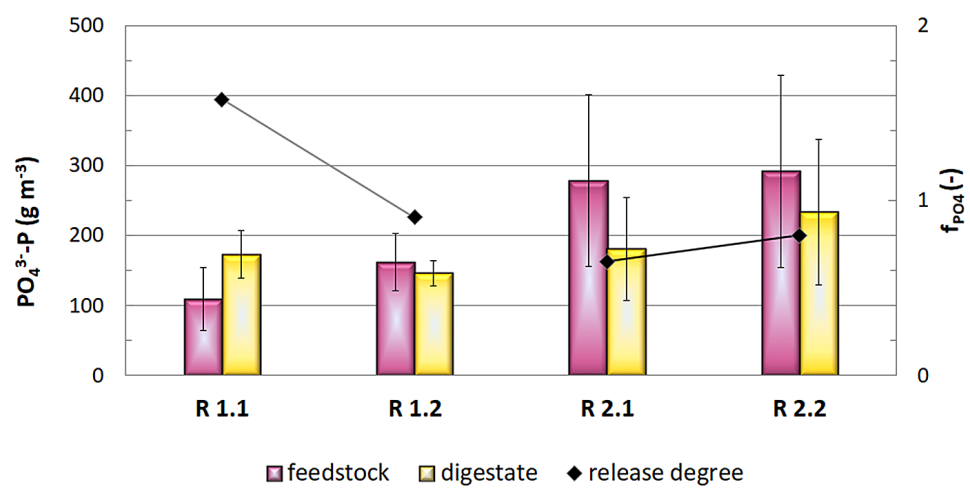

Fig. 2. The concentration of a) total phosphorus b) orthophosphate in the feedstock and digestate (average values) and a) the removal efficiency of TP $\eta$ and $b$ ) release degree $f_{\mathrm{PO} 4}$ (confidence limits $\alpha=0.05$ ) 
ammonification, the ammonia release was obtained and lower concentration of total nitrogen and total phosphorus was achieved in the digestate, probably due to partial retention in the digesters due to the precipitation processes. It can be supposed that due to precipitation, the release of orthophosphate could not be observed. The results indicated that the cheese whey addition did not contribute to the deterioration of the digestate quality, which is technologically beneficial and cost-effective.

\section{REFERENCES}

1. Act of 14 December 2012 On Waste (Dz. U. 2013 Poz. 21) (In Polish).

2. Akhiar A., Battimelli A., Torrijos M., Carrere H. 2017. Comprehensive characterization of the liquid fraction of digestates from full-scale anaerobic codigestion. Waste Management, 59, 118-128.

3. APHA, 2005. Standard methods for the examination of water and waste water, 21st Edn, American Public Health Association, Washington.

4. Banks Ch.J., Chesshire M., Heaven S., Arnold R. 2011. Anaerobic digestion of source-segregated domestic food waste: Performance assessment by mass and energy balance. Bioresource Technology, 102(2), 612-620.

5. Bertin L., Grilli S., Spagni A., Fava F. 2013. Innovative two-stage anaerobic process for effective codigestion of cheese whey and cattle manure. Bioresource Technology, 779-783.

6. Charalambous P., Shin J., Shin S.G., Vyrides I. 2020. Anaerobic digestion of industrial dairy wastewater and cheese whey. Performa, 147(1), 1-10.

7. Chatzipaschali A.A., Stamatis A.G. 2012. Biotechnological Utilization with a Focus on Anaerobic Treatment of Cheese Whey: Current Status and Prospects. Energies, 5(9), 3492-3525.

8. Czekała W., Lewicki A., Pochwatka P., Czekała A., Wojcieszek D., Jóźwiakowski K., Waliszewska H., 2020. Digestate management in polish farms as an element of the nutrient cycle. Journal of Cleaner Production, 242, 118454.

9. De Wit J.N. 2001. Lecturer's handbook on whey and whey products. European Whey Products Association.

10. Elalami D., Carrere H., Monlau F., Abdelouahdi K., Oukarroum A., Barakate A. 2019. Pretreatment and co-digestion of wastewater sludge for biogas production: Recent research advances and trends. Renewable and Sustainable Energy Reviews 114, 109287.
11. Escalante H., Castro L., Amaya M.P., Jaimes L., Jaimes-Estévez J. 2018. Anaerobic digestion of cheese whey: Energetic and nutritional potential for the dairy sector in developing countries. Waste Management 71, 711-718.

12. Feki E., Battimelli A., Savadi S., Dhouib A., Khoufi S. 2020. High-Rate Anaerobic Digestion of Waste Activated Sludge by Integration of Electro-Fenton Process. Molecules, 25(3), 626.

13. Fouda S., von Tucher S., Lichti F., Schmidhalter U. 2013. Nitrogen availability of various biogas residues applied to ryegrass. Journal of Plant Nutrition and Soil Science, 176, 572-584.

14. Fuchs W., Drosg B. 2013. Assessment of the state of the art of technologies for the processing of digestate residue from anaerobic digesters. Water Science \& Technology, 67, 1984-1993.

15. Hublin A., Zelić B. 2013. Modelling of the whey and cow manure co-digestion process. Waste Management \& Research, 31(4), 353-360.

16. Kim J., Yu Y., Lee Ch. 2013. Thermo-alkaline pretreatment of waste activated sludge at low-temperatures: Effects on sludge disintegration, methane production, and methanogen community structure. Bioresource Technology, 144, 194-201.

17. Kleyböcker A., Liebrich M,. Kasina M., Kraume M., Wittmaier M., Würdemanna H. 2011. Comparison of different procedures to stabilize biogas formation after process failure in a thermophilic waste digestion system: Influence of aggregate formation on process stability. Waste Management, 32(6), 1122-1130.

18. Logan M., Visvanathan Ch. 2019. Management strategies for anaerobic digestate of organic fraction of municipal solid waste: Current status and future prospects. Waste Management \& Research, 37(1), 27-39.

19. Maragkaki A.E., Vasileiadis I., Fountoulakis M., Kyriakou A., Lasaridi K., Manios T. 2018. Improving biogas production from anaerobic co-digestion of sewage sludge with a thermal dried mixture of food waste, cheese whey and olive mill wastewater, Waste Management, 71, 644-651.

20. Maragkaki A.E., Fountoulakis M., Gypakis A., Kyriakou A., Lasaridi K., Manios T. 2017. Pilotscale anaerobic co-digestion of sewage sludge with agro-industrial by-products for increased biogas production of existing digesters at wastewater treatment plants. Waste Management, 59, 362-370.

21. Marcato C.E., Pinelli E., Pouech P., Winterton P., Guiresse M. 2008. Particle size and metal distributions in anaerobically digested pig slurry. Bioresour. Technol., 99, 2340-2348.

22. Martínez-Ruano J.A., Restrepo-Serna D.L., Carmona-Garcia E., Giraldo J.A.P., Aroca G., Cardona C.A. 2019. Effect of co-digestion of milk-whey and 
potato stem on heat and power generation using biogas as an energy vector: techno-economic assessment. Applied Energy, 241, 504-518.

23. Massé D.I., Croteu F., Massé L. 2007. The fate of crop nutrients during digestion of swine manure in psychrophilic anaerobic sequencing batch reactors. Bioresource Technology, 93, 2819-2823.

24. Möller K., Müller T. 2012. Effects of anaerobic digestion on digestate nutrient availability and crop growth: A review Bioresource Technology. Engineering in Life Sciences, 12(3), 242-257.

25. Monlau F., Francavilla M., Sambusiti C., Antoniou N., Solhy A., Libutti A., Zabaniotou A., Barakat A., Monteleone M. 2016. Toward a functional integration of anaerobic digestion and pyrolysis for a sustainable resource management. Comparison between solid-digestate and its derived pyrochar as soil amendment. Appl. Energy, 169, 652-662.

26. Montusiewicz A. 2015. Impact of bioaugmentation on nutrient release in anaerobic digestion of sewage sludge. Proceedings of ECOpole, 9(1), 269-277.

27. Montusiewicz A., 2012. Współfermentacja osadów ściekowych i wybranych kosubstratów jako metoda efektywnej biometanizacji. Monografie Komitetu Inżynierii Środowiska Polskiej Akademii Nauk, vol. 98, Lublin (in Polish).

28. Montusiewicz A., Lebiocka M., Szaja A. 2013. Variability of nutrients in co-digestion of sewage sludge and old landfill leachate, In: Environmental Engineering IV. Pawłowski A, Dudzińska M.R., Pawłowski L., editors. London: CRC Press, 225-230.

29. O’Brien B.J., Milligan E., Carver J. Roy E.D. 2019. Integrating anaerobic co-digestion of dairy manure and food waste with cultivation of edible mushrooms for nutrient recovery. Bioresource Technology, 285, 121312.

30. Ong L., Dagastine R.R., Kentish S.E., Gras S.L. 2013. Microstructure and Composition of Full Fat Cheddar Cheese Made with Ultrafiltered Milk Retentate. Foods (Basel, Switzerland), 2(3), 310-331.

31. Peng W., Lü F., Hao L., Zhang H., Shao L., He P. 2020a. Digestate management for high-solid anaerobic digestion of organic wastes: A review. Bioresour Technology, 297, 122485.

32. Peng W., Pivato A. 2019. Sustainable Management of Digestate from the Organic Fraction of Municipal Solid Waste and Food Waste Under the Concepts of Back to Earth Alternatives and Circular Economy, Waste and Biomass Valorization 10, 465-481.

33. Peng W., Pivato A., Cerminara G., Gabro F., Raga R. 2020b. Denitrification of Mature Landfill Leachate with High Nitrite in Simulated Landfill Columns Packed with Solid Digestate from Organic Fraction of Municipal Solid Waste. Waste and Biomass
Valorization, 11, 411-421.

34. Peng W., Pivato A., Lavagnolo M.C., Raga R. 2018. Digestate application in landfill bioreactors to remove nitrogen of old landfill leachate. Waste Management, 74, 335346.

35. Prazeres A.R., Carvalho F., Rivas J. 2012. Cheese whey management: A review. Journal of Environmental Management 110, 48-68.

36. Przywara L. 2006. Warunki i możliwości usuwania fosforanów i fosforu ogólnego ze ścieków przemysłowych. Rozprawa Doktorska. Politechnika Krakowska im. Tadeusza Kościuszki, Bielsko-Biała (in Polish).

37. Rico C., Muñoz N., Fernández J., Rico J.L. 2015. High-load anaerobic co-digestion of cheese whey and liquid fraction of dairy manure in a one-stage UASB process: limits in co-substrates ratio and organic loading rate. Chem. Eng. J., 262, 794-802.

38. Risberg K., Cederlund H., Pell M., Arthurson V., Schnürer A. 2017. Comparative characterization of digestate versus pig slurry and cow manure - Chemical composition and effects on soil microbial activity. Waste Management, 61, 529-538.

39. Ryan M.P., Walsh G. 2016. The biotechnological potential of whey. Rev. Environ. Sci. Biotechnol., 15, 479-498.

40. Sheets J.P., Yang L., Ge X., Wang Z., Li Y. 2015. Beyond land application: emerging technologies for the treatment and reuse of anaerobically digested agricultural and food waste. Waste Management, 44, 94-115.

41. Sosnowski P., Wieczorek A., Ledakowicz S. 2003. Anaerobic co-digestion of sewage sludge and organic fraction of municipal solid wastes. Advances in Environmental Research, 7, 609-616.

42. Stefaniuk M., Oleszczuk P. 2015. Characterization of biochars produced from residues from biogas production. Journal of Analytical and Applied Pyrolysis, 115, 157-165.

43. Suzuki K., Tanaka Y., Kuroda K., Hanajima D., Fukumoto Y., Yasuda T., Waki M. 2007. Removal and recovery of phosphorous from swine wastewater by demonstration crystallization reactor and struvite accumulation device. Bioresource Technology, 98, 1573-1578.

44. Tambone F., Scaglia B., D’Imporzano G., Schievano A., Orzi V., Salati S., Adani F. 2010. Assessing amendment and fertilizing properties of digestates from anaerobic digestion through a comparative study with digested sludge and compost. Chemosphere, 81(5), 577-583.

45. Tampio E., Salo T., Rintala J. 2016. Agronomic characteristics of five different urban waste digestates. Journal of Environmental Management, 169, 293-302. 
46. Teglia C., Tremier A., Martel J. 2011. Characterization of solid digestates: part 2, assessment of the quality and suitability for composting of six digested products. Waste and Biomass Valorization, 2, 113-126.

47. Treu L., Tsapekos P., Peprah M., Campanaro S., Giacomini A., Corich V. 2019. Microbial profiling during anaerobic digestion of cheese whey in reactors operated at different conditions. Bioresource Technology, 275, 375-385.

48. Vaneeckhaute C., Lebuf V., Michels E., Belia E., Vanrolleghem P.A., Tack F.M., Meers E. 2017. Nutrient recovery from digestate: systematic technology review and product classification. Waste and Biomass Valorization, 8(1), 21-40.

49. Vivekanand V., Mulat D.G., Eijsink V.G.H., Horn S.J. 2018. Synergistic effects of anaerobic co-digestion of whey, manure and fish ensilage. Bioresource Technology, 249, 35-41.
50. Voća N., Krička T., Ćosić T., Rupić V., Jukić Ž., Kalambura S. 2005. Digested residue as a fertilizer after the mesophilic process of anaerobic digestion Plant. Soil Environ., 51, 262-266.

51. Xia J., Murphy J.D. 2016. Microalgal Cultivation in Treating Liquid Digestate from Biogas Systems. Trends in Biotechnology, 34(4), 264-275.

52. Xu F., Li Y., Ge X., Yang L., Li Y. 2018. Anaerobic digestion of food waste - challenges and opportunities. Bioresource Technology, 247, 1047-1058.

53. Zhen G., Lu X., Kato H., Zhao Y., Li Y.Y. 2017. Overview of pretreatment strategies for enhancing sewage sludge disintegration and subsequent anaerobic digestion: Current advances, full-scale application and future perspectives. Renewable Sustainable Energy Rev., 69, 559-577.

54. Zirkler D., Peters A., Kaupenjohann M. 2014. Elemental composition of biogas residues: Variability and alteration during anaerobic digestion. Biomass and Bioenergy, 67, 89-98. 